\title{
Peran Pemangku Kepentingan Dalam Revitalisasi Sungai Tawing Untuk Mengatasi Bencana Banjir Di Kabupaten Trenggalek
}

\author{
Windiani
}

\begin{abstract}
ABSTRAK
Revitalisasi Sungai Tawing merupakan langkah yang mendesak untuk dilakukan dalam rangka mengatasi bencana banjir dan menunjang kebutuhan sarana irigasi pertanian. Hingga saat ini, sektor pertanian masih menjadi salah satu andalan mata pencaharian bagi petani di wilayah Trenggalek. Berdasarkan hasil observasi di lapangan, keberadaan Sungai Tawing sebagai sumber daya air telah mengalami degradasi lingkungan yang mengkawatirkan bagi keberlanjutan sektor pertanian. Selain telah mengalami pendangkalan, beberapa titik lokasi telah beralih fungsi sebagai tempat pembuangan sampah dan digunakan sebagai sarana untuk membuang limbah kotoran ternak milik penduduk setempat. Debit air juga mengalami penurunan drastis pada saat musim kemarau, dan mengalami peluapan saat musim hujan sehingga menimbulkan banjir bandang yang parah di sekitar kawasan sungai. Hasil penelitian menunjukkan bahwa belum optimalnya peran pemangku kepentingan baik dari pemimpin lokal, tokoh dan masyarakat yang berada di sekitar sungai Tawing menjadi salah satu kendala dalam pengelolaan lingkungan dan mengatasi banjir di wilayah studi.
\end{abstract}

Kata Kunci: Peran, Pemangku Kepentingan, Revitalisasi, banjir

Kabupaten Trenggalek merupakan salah satu daarah rawan bencana yang ada di Jawa Timur. Berdasarkan peta daerah rawan bencana yang dikeluarkan Pemerintah Propinsi Jawa Timur, terdapat 7 dari 13 kecamatan yang ada di Trenggalek termasuk wilayah rawan banjir dan tanah longsor. Salah satu faktor penyebabnya adalah curah hujan yang tinggi dan secara geografis merupakan daerah pegunungan sehingga sungai meluap ke daratan karena tidak mampu menampung debit air yang sangat tinggi. Berikut ini data wilayah dampak banjir yang terjadi di Kabupaten Trenggalek bulan Mei 2011.

Di kabupaten Trenggalek bencana banjir dan tanah longsor terjadi hampir tiap tahun dan khusus yang terjadi pada bulan Mei 2011 yang lalu cukup menimbulkan keprihatinan. Ada tujuh kecamatan di Kabupaten Trenggalek, terendam banjir hingga setinggi 1,5 meter. Selain itu, di beberapa titik di wilayah tersebut juga terjadi longsor, sehingga mengisolasi dua kecamatan. Bencana tersebut terjadi setelah hujan deras yang mengguyur Trenggalek sejak Kamis (19/5 
2011) malam. Tujuh kecamatan yang dilanda banjir adalah Munjungan, Kampak, Trenggalek Kota, Gandusari, Watulimo, Karangan, dan, Panggul.

\begin{tabular}{|c|c|c|c|c|c|c|}
\hline \multirow[t]{2}{*}{ No } & \multirow[t]{2}{*}{ Kab/Kota } & \multirow{2}{*}{$\begin{array}{l}\text { Nama } \\
\text { Sungai }\end{array}$} & \multicolumn{2}{|c|}{ Lokasi } & \multirow{2}{*}{$\begin{array}{l}\text { Tanggul } \\
\text { Kritis } \\
\text { (m) }\end{array}$} & \multirow{2}{*}{$\begin{array}{l}\text { Durasi banjir } \\
\text { (jam) dan } \\
\text { ketinggian (m) }\end{array}$} \\
\hline & & & Kec. & Desa & & \\
\hline & Trenggalek & $\begin{array}{l}\text { Kali } \\
\text { Tawing }\end{array}$ & Kampak & $\begin{array}{l}\text { Karangrejo } \\
\text { Bendoagung } \\
\text { Senden } \\
\text { Sugihan } \\
\text { Ngadimulyo }\end{array}$ & $\begin{array}{l}0,5 \\
1,5 \\
0,5 \\
1,5 \\
1,5\end{array}$ & $\begin{array}{l}12 \mathrm{jam} / 1,5 \mathrm{~m} \\
10 \mathrm{jam} / 0,75 \mathrm{~m} \\
6 \mathrm{jam} / 0,5 \mathrm{~m} \\
10 \mathrm{jam} / 0,5 \mathrm{~m} \\
11 \mathrm{jam} / 1 \mathrm{~m}\end{array}$ \\
\hline & & & Gandusari & $\begin{array}{l}\text { Nrayung } \\
\text { Jajar } \\
\text { Wonoanti } \\
\text { Sukorejo } \\
\text { Gandusari } \\
\text { Widoro } \\
\text { Sukoanyar } \\
\text { Krendengan } \\
\text { Melis }\end{array}$ & $\begin{array}{l}, 5 \\
4,5 \\
- \\
- \\
3,00 \\
3,00 \\
3,00 \\
3,00 \\
3,00 \\
\end{array}$ & $\begin{array}{l}8 \mathrm{jam} / 0,5 \mathrm{~m} \\
8 \mathrm{jam} / 0,5 \mathrm{~m} \\
11 \mathrm{jam} / 0,5 \mathrm{~m} \\
12 \mathrm{jam} / 0,5 \mathrm{~m} \\
8 \mathrm{jam} / 0,5 \mathrm{~m} \\
12 \mathrm{jam} / 1 \mathrm{~m} \\
10 \mathrm{jam} / 0,5 \mathrm{~m} \\
10 \mathrm{jam} / 0,5 \mathrm{~m} \\
8 \mathrm{jam} / 0,5 \mathrm{~m}\end{array}$ \\
\hline & & $\begin{array}{l}\text { Kali } \\
\text { Ngasinan }\end{array}$ & Pogalan & $\begin{array}{l}\text { Kedungluran } \\
\text { Ngadirejo }\end{array}$ & $\begin{array}{l}3,00 \\
1,5\end{array}$ & $\begin{array}{l}9 \mathrm{jam} / 0,5 \mathrm{~m} \\
9 \mathrm{jam} / 05 \mathrm{~m}\end{array}$ \\
\hline & & Parit raya & Pogalan & Pogalan & & $8 \mathrm{jam} / 05 \mathrm{~m}$ \\
\hline & & $\begin{array}{l}\text { Kali } \\
\text { Ngrempo }\end{array}$ & Munjungan & Bendoroto & 1,5 & $10 \mathrm{jam} / 1 \mathrm{~m}$ \\
\hline & & $\begin{array}{l}\text { Kali } \\
\text { Ngemplak }\end{array}$ & Watulimo & $\begin{array}{l}\text { Prigi } \\
\text { Margomulyo }\end{array}$ & $\begin{array}{l}3 \\
3 \\
\end{array}$ & $\begin{array}{l}8 \mathrm{jam} / 0,75 \mathrm{~m} \\
8 \mathrm{jam} / 0,75 \mathrm{~m}\end{array}$ \\
\hline & & $\begin{array}{l}\text { Kali } \\
\text { Gedangan }\end{array}$ & Panggul & $\begin{array}{l}\text { Wonocoyo } \\
\text { Nglembung } \\
\text { Panggul } \\
\text { Barang } \\
\text { Banjar }\end{array}$ & $\begin{array}{l}3 \\
3 \\
3 \\
3 \\
3 \\
\end{array}$ & $\begin{array}{l}8 \mathrm{jam} / 0,5 \mathrm{~m} \\
8 \mathrm{jam} / 0,5 \mathrm{~m} \\
8 \mathrm{jam} / 0,5 \mathrm{~m} \\
7 \mathrm{jam} / 0,5 \mathrm{~m} \\
7 \mathrm{jam} / 0.5 \mathrm{~m}\end{array}$ \\
\hline
\end{tabular}

Sumber: Diolah dari data Balai PSAW Jawa Timur Tahun 2011

Kecamatan Munjungan dan Kampak merupakan daerah terparah akibat banjir dan longsor. Meskipun pada Jumat (20/5) siang banjir mulai surut, dampak banjir dan longsor masih terlihat di kedua kecamatan. Di Kecamatan Kampak misalnya tumpukan material longsor membuat jalur utama yang menghubungkan kecamatan Kampak dengan Munjungan terputus total. Material longsor yang terdiri lumpur dan pasir menutup badan jalan sepanjang lebih dari 50 meter di Desa Ngadimulyo. Di lokasi tersebut juga terdapat satu rumah yang ambruk akibat diterjang longsor. Sedangkan di Kecamatan Munjungan, terjangan banjir merobohkan tiga tiang penyangga jembatan Bungu. Akibatnya, jembatan tersebut 
tidak bisa dilewati. Begitu pula, dua kelas bangunan Madrasah Ibtidaiyah di Munjungan roboh tersapu air bah sehingga aktivitas belajar mengajar disekolah terpaksa diliburkan. Tercatat 4 korban meninggal dunia tertimpa rumah roboh dan 4 orang luka berat dan 8 orang luka ringan. Diperkirakan kerugian material akibat banjir terbut mencapai 3,2 milyar rupiah. Diskripsi banjir Trenggalek bulan Mei 2011 dapat dicermati dari gambar-gambar berikut.

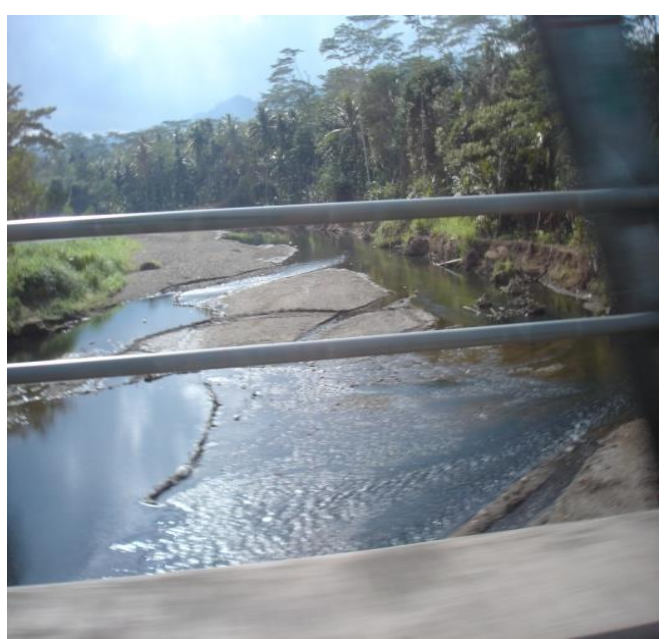

Gambar 1

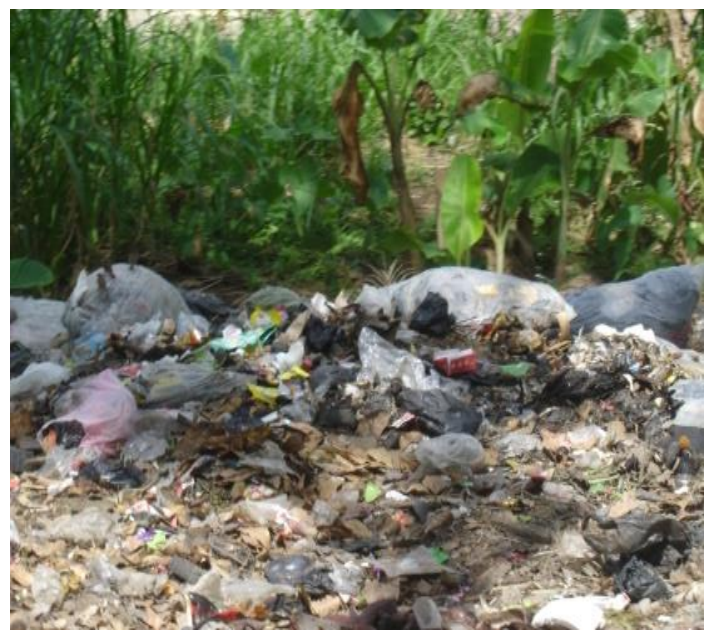

Gambar 2

Keterangan: Kondisi sungai Tawing musim kemarau dan sampah di bibir sungai.

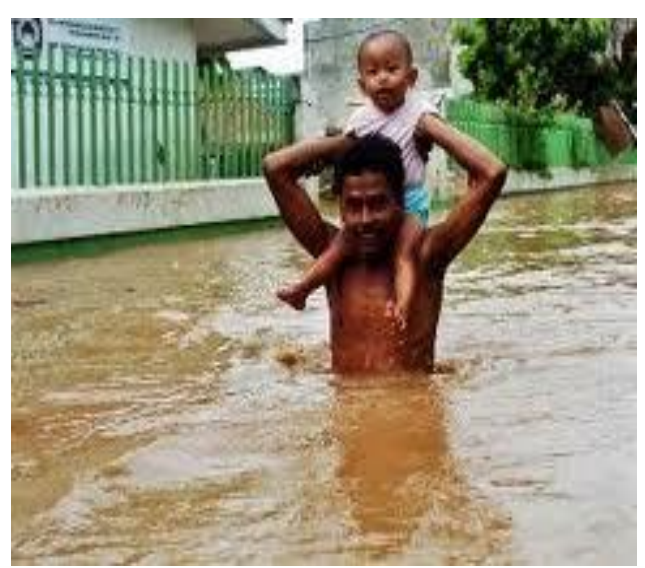

Gambar 3

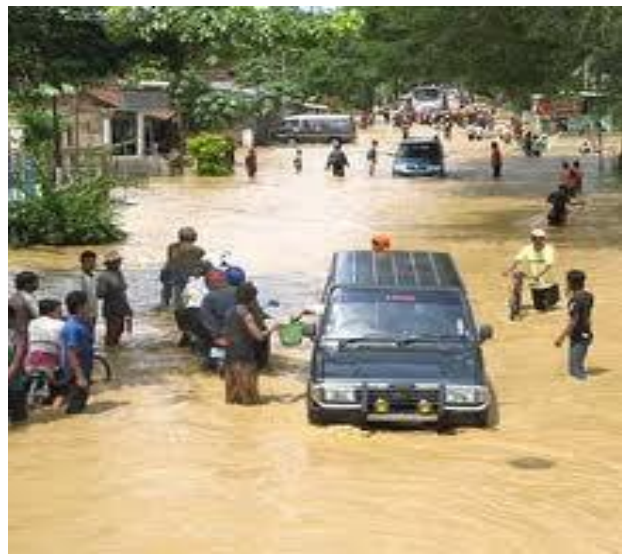

Gambar 4

Gambar 3 dan gambar 4 adalah Sungai Tawing saat banjir dan meluap ke jalan raya 


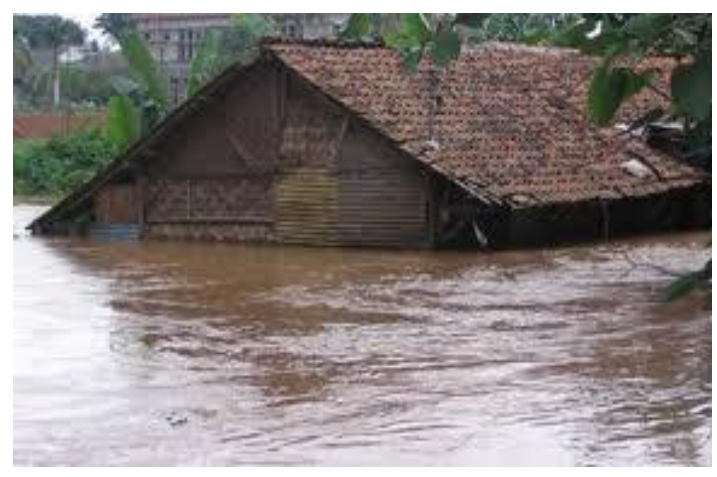

Gambar 5

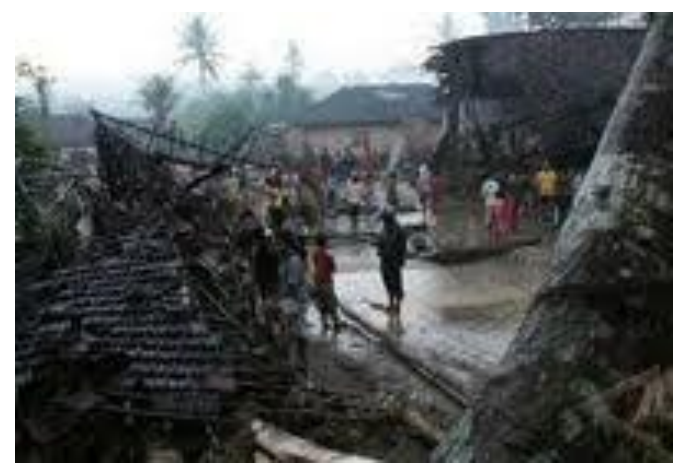

Gambar 6

Gambar 5 dan 6 20/5'11 menyebabkan rumah terndam dan roboh.

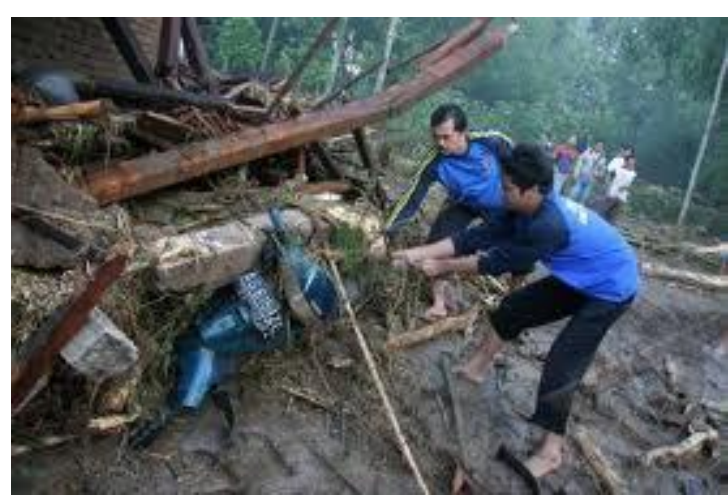

Gambar 7

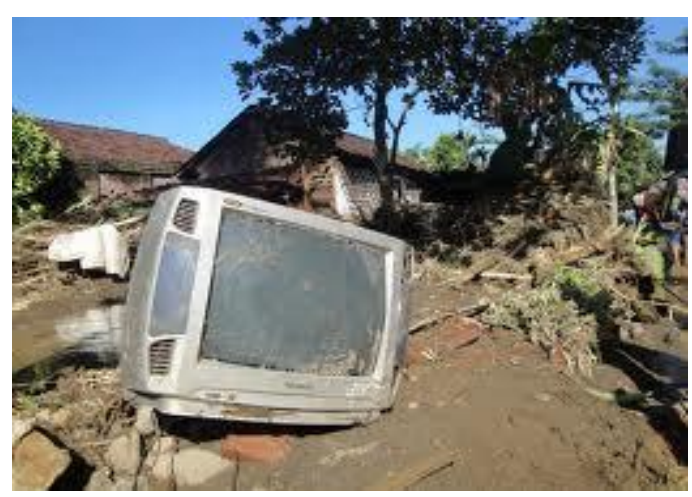

Gambar 8

Gambar 7 dan 8 Tim Taruna siaga mencari korban banjir dan Perabotan elektronik terseret banjir

Berdasarkan latar belakang tersebut, permasalahan yang hendak dijawab dalam penelitian ini adalah ingin mengetahui sejauh mana peran pemangku kepentingan baik pemerintah setempat, tokoh masyarakat dan masyarakat yang ada di sekitar sungai Tawing dalam melakukan upaya revitalisasi agar sungai dapat berfungsi secara optimal untuk menampung debit air, sehingga dapat mengurangi resiko bencana banjir pada saat musim hujan.

\section{Kajian Teoritis Penanggulangan bencana}

Bencana adalah suatu gangguan serius terhadap keberfungsian suatu masyarakat sehingga menyebabkan kerugian yang meluas pada kehidupan manusia dari segi materi, ekonomi maupun lingkungan, dan melampaui kemampuan 
masyarakat yang bersangkutan untuk mengatasi dengan menggunakan sumberdaya mereka sendiri (Puji-Pujiono, 2005). Bencana banjir dan tanah longsor kabupaten Trenggalek bulan Mei 2011 lalu tergolong besar dterutama jika dilihat dari akibat yang ditimbulkan baik dari segi jumlah korban, kerusakan-kerusakan yang ditimbulkannya, baik kerusakan rumah, lahan pertanian, sarana-prasarana dan korban jiwa.

Secara alami, Indonesia adalah negeri yang rawan bencana. Kondisi ini makin diperparah oleh perilaku manusia yang merusak lingkungan dengan sengaja maupun tidak sengaja. Perilaku tersebut ditambah minimnya pendidikan tentang bencana sehingga jika terjadi bencana maka yang dilakukan hanya recovery (pemulihan ke keadaan semula). Padahal recovery tidak cukup apalagi jika dimaknai sebagai pemulihan fisik, yakni sekedar membuatkan rumah-rumah tempat tinggal sebagai pengganti rumah-rumah yang rusak akibat bencana. Recovery (pemulihan) dalam arti yang luas sebagai pemulihan fisik, sosial dan mental terhadap masyarakat korban bencana. Pengabaian terhadap aspek sosial dan mental menjadikan permasalahan pasca bencana pada masyarakat korban bencana tidak terselesaikan secara utuh. Kekuranglengkapan recovery tersebut perlu diteliti secara mendalam sehingga dalam jangka panjang recovery juga bermakna mitigation (mengurangi resiko bencana) dan ketahanan (resilience) terhadap bencana.

Menurut Prof. Dr. Sutikno, mantan Kepala Pusat Studi Bencana Alam UGM, setidaknya ada 3 hal yang ikut andil menjadi penyebab terjadinya banyak bencana alam dewasa ini: 1) Global Warning (pemanasan global), 2) alih fungsi lahan dan penataan ruang yang tidak tepat, 3) berkurangnya jumlah hutan (Sutikno, 2008). Masalah pemanasan global merupakan ancaman seluruh muka bumi yang tak dapat dihindari, peningkatan suhu rata-rata bumi mengganggu kestabilan lingkungan alam, air dan cuaca sehingga menimbulkan banyak bencana alam. Perubahan alih fungsi lahan karena meningkatnya pertumbuhan penduduk sehingga memerlukan pemukiman. Padatnya pemukiman tidak hanya di perkotaan tetapi juga merambah ke wilayah-wilayah hutan dan lereng pegunungan. Di Indonesia, penebangan hutan juga terus dilakukan baik secara legal maupun illegal. 
Di Propinsi Jawa Timur, semua kabupaten tanpa kecuali adalah rawan bencana banjir; sedangkan rawan bencana longsor terdapat di 20 kabupaten dari 30 kabupaten yang ada. Data Peta Rawan Bencana Jawa Timur, rata-rata setiap daerah berpotensi setidak-tidaknya 8 sampai 15 jenis ancaman bencana: mulai dari gunung meletus, gempa bumi, banjir, longsor, angin puyuh, kekeringan, tsunami, epidemi, kecelakaan industri, dan seterusnya ( Jawa Pos, 16 Juli 2007). Beberapa waktu terakhir, sepanjang 2007 sampai awal 2011 Jawa Timur dilanda bencana banjir dimana-mana; mulai meluapnya sepanjang aliran Sungai Bengawan Solo pada bulan Desember 2007-Januari 2008 yang merendam wilayah Ngawi, Bojonegoro, Trenggalek, Lamongan, Tuban dan Gresik (Kompas, 25 Januari 2008). Bencana banjir bandang merusak permukiman dan perkotaan di wilayah Trenggalek tahun 2007 dan Situbondo dan Bondowoso pada 9 Februari 2008, mengakibatkan 12 orang meninggal dan kerugian ditaksir mencapai Rp.300 milyar lebih. Kemudian disusul banjir dan tanah longsor pada tanggal 12 Februari 2008 yang meluluh-lantakkan 22 rumah dalam dan satu orang meninggal, di kecamatan Mlanding, Situbondo (Kompas, 10-14 Februari 2008'; Jawa Pos, 10-14 Februari 2008). Menilik dari data diatas, dibutuhkan suatu manajemen penanganan pascabencana yang meliputi fisik, sosial dan mental secara utuh. Manajemen penanganan pascabencana yang selama ini dilakukan di Indonesia, dalam prakteknya tidak dilaksanakan secara utuh yakni hanya memulihkan secara fisik saja, belum memulihkan aspek social dan mental masyarakat korban bencana. Akibat belum dipulihkannya aspek social dan mental masyarakat korban bencana menjadikan mereka tidak memiliki ketahanan terhadap bencana. Mereka lamban memulihkan dirinya sendiri, dan semakin rentan jika ancaman bencana berulang terjadi. Masyarakat korban hanya mengandalkan bantuan dan recovery dari pemerintah dan pihak-pihak lain tanpa ada daya untuk memulihkan dirinya sendiri. Penanganan pascabencana menjadi kasus krusial terhadap siapa yang paling bertanggungjawab menjadi penyebab bencana tersebut. Ironisnya, yang kerap disalahkan justru masyarakat yang tertimpa bencana tersebut. Masyarakat sering dituding menjadi pelaku ilegal logging pada hutan dilingkungannya. Hal lainnya yang dituduhkan adalah kesalahan pola penanaman 
area perkebunan dengan tanaman nonkeras. Sederet kesalahan tersebut tidak dapat menyelesaikan masalah (Agus Hilman dalam Jawa Pos, 14 Januari 2006).

Masalah yang mendesak dan merupakan masalah riil di lapangan adalah bagaimana pemulihan masyarakat korban bencana harus dilakukan dan sejauh mana modal dasar untuk hal itu telah dimiliki, termasuk bagaimana agar bencana tersebut (dengan korban-korbannya yang fatal) menjadi media pembelajaran agar tidak perlu terulang kembali. Pada dasarnya masyarakat harus dilatih kemampuannya dalam beradaptasi dan memperlakukan lingkungan secara bijaksana. Sehingga diperlukan suatu strategi adaptasi yang dikembangkan oleh masyarakat itu sendiri untuk mengatur daya tahan (resiliance) terhadap persoalan-persoalan yang mereka hadapi (Ary Wahyono, dkk, 2001).

Salah satu hal penting yang belum digarap secara seksama selama ini adalah Water Culture. Water Culture diartikan sebagai kepahaman masyarakat sosial tentang masalah pemanfaatan air dan konservasi air yang ada di sekitar mereka. Pada masyarakat tradisional baik di Jawa maupun di luar Jawa, sebenarnya telah mengenal sosio-hidraulik. Tanpa upaya membudayakan kesadaran seluruh masyarakat bahwa air merupakan hal penting yang perlu dilindungi dan dijaga dengan metode-metode yang dikuasai masyarakat, maka upaya apapun tidak mampu menyelamatkan air dan seluruh komponen lingkungan yang terkait, termasuk keselamatan manusia itu sendiri (Maryono, 2005).

Baik pendekatan Teori Ekologi Zona Lingkungan maupun Water Culture mengandaikan masyarakat sebagai subjek bagi dirinya sendiri. Hasil penelitian yang telah dilakukan oleh Seodarso, dkk pada tahun 2007 tentang Strategi Adaptasi Masyarakat Kabupaten Jember Terhadap Lingkungan Sekitar Pasca Bencana Banjir menemukan bahwa persoalan yang muncul pada masyarakat pascabencana adalah mereka tidak diposisikan sebagai subjek melainkan objek. Masyarakat sebagai objek dari suatu kebijakan pemerintahan tanpa memiliki daya tawar. Termasuk berkaitan dengan posisi dengan lingkungan, masyarakat seringkali dihadapkan pada ketiadaan memilih, setidaknya inilah yang dihadapi para korban bencana banjir dan tanah longsor di Jember. Rumah dan lingkungan bagi korban bencana telah disiapkan dan 
diatur sedemikian rupa oleh pemerintah, karena ketakberdayaannya masyarakat tak memiliki pilihan.

Hasil penelitian di atas merekomendasikan beberapa hal penting yang perlu menjadi catatan bagi perencana pembangunan dan penyusun peraturan daerah di Jawa Timur pada umumnya dan Kabupaten Jember pada khususnya diantaranya adalah perlunya penanganan korban bencana dari sisi kemanusiaannya yakni keseimbangan antara fisik, sosial dan mental masyarakat. Hal tersebut dapat dilakukan dengan : Pertama, pendekatan berupa pendampingan pemerintah dan pihak-pihak terkait terhadap masyarakat korban bencana alam pascabencana. Kedua, rencana dan pelaksanaan tahap-tahap pemberdayaan kembali masyarakat korban bencana. Ketiga, keterjalinan komunikasi yang lancar antara Pemerintah Daerah Jember dengan masyarakat korban bencana agar tidak menimbulkan prasangka terhadap upaya recovery dan mitigation yang dilakukan pemerintah.

\section{Deskripsi Sungai Tawing dan Kehidupan Masyarakat Di Kawasan Sungai}

Sungai Tawing merupakan salah satu dari 28 sungai yang ada di Kabupaten Trenggalek. Mengalir di dua kecamatan yaitu Kecamatan Kampak dan Kecamatan Gandususari. Sungai Tawing berhulu di Desa Ngadimulyo, Bogoran dan Desa Bendoagung. Panjang sungai Tawing antara $17 \mathrm{~km}$ yang melintasi beberapa desa di dua Kecamatan. Sungai Tawing banyak dimanfaatkan masyarakat di Kawasan sungai untuk pemenuhan kebutuhan pengairan areal persawahan. Sebagaian besar masyarakat yang tinggal di kawasan sungai Tawing bermata pencaharian sebagai petani dan buruh tani dengan jenis lahan sawah, ladang dan hutan, sebagian lainnya bermata pencaharian sebagai pedagang dan pegawai negeri.

Sungai Tawing memiliki luas sekitar 100 meter dengan kedalaman sekitar 57 meter. Kondisi Sungai Tawing saat ini mengalami pendangkalan dan abrasi yang rawan menimbulkan bencana banjir. Kasus terjadinya banjir bulan Juli 2011 yang lalu dan banjir-banjir yang terjadi sebelumnya menunjukkan daya tampung sungai semakin berkurang. Kondisi ini diperparah dengan banyaknya sampah plastik yang terikut di sungai. Pada saat banjir (Juli 2011) ketinggian air Sungai Tawing bisa 
mencapai 12 meter yang menyebabkan tenggelamnya permukiman di kawasan sekitar sungai hingga 1-2 meter mulai dari bibir sungai hingga radius $1 \mathrm{~km}$.

\section{Sungai Tawing Dan Bencana Banjir}

Sungai Tawing merupakan salah satu sungai yang ada di kabupaten Trenggalek yang berhulu di kecamatan Kampak dan memiliki hilir hingga di Kecamatan Gandusari. Sungai Tawing membentang sepanjang kurang lebih 30-40 km yang melintasi 4 desa di Kecamatan Kampak dan 6 desa di kecamatan Gandusari.

\begin{tabular}{|l|l|}
\hline Kecamatan & \multicolumn{1}{|c|}{ Desa } \\
\hline \multirow{4}{*}{ Kampak } & Bogoran \\
\cline { 2 - 2 } & Ngadimulyo \\
\cline { 2 - 2 } & Bendoagung \\
\cline { 2 - 2 } & Senden \\
\cline { 2 - 2 } & Sugihan \\
\hline \multirow{4}{*}{ Gandusari } & Ngrayung \\
\cline { 2 - 2 } & Wonorejo \\
\cline { 2 - 2 } & Sukorejo \\
\cline { 2 - 2 } & Gandusari \\
\cline { 2 - 2 } & Mulis \\
\cline { 2 - 2 } & Widoro \\
\hline
\end{tabular}

Sumber: Data diolah dari Kecamatan Kampak Dalam Angka

Bencana banjir yang terjadi pada tanggal 19-20 Juni 2011 yang lalu enimbulkan berbagai dampak bagi lingkungan sekitar. Dari bencana banjir tersebut teridentifikasi kerusakan-kerusakan di sekitar sungai Tawing: merobohkan 4 rumah, 2 korban meninggal daan puluhan luka-luka, hal ini belum termasuk kerugian material lain yang terseret arus banjir sungai Tawing.

Tujuh kecamatan di Kabupaten Trenggalek, Jawa Timur, terendam banjir hingga setinggi 1,5 meter. Bencana tersebut terjadi setelah hujan deras yang mengguyur Trenggalek kota sejak Kamis (19/5) malam. Tujuh kecamatan yang dilanda banjir adalah Kunjungan, Kampak, Trenggalek,Gandusari,Watulimo,Karangan,dan Kecamatan Panggul. Kecamatan Kampak dan Munjungan merupakan daerah terparah akibat banjir dan longsor. Meskipun Jumat (20/5) siang banjir mulai surut, dampak banjir dan longsor masih terlihat di wilayah tersebut. Kecamatan Kampak misalnya tumpukan material 
longsor membuat jalur utama yang menghubungkan Kecamatan Kampak dengan Munjungan terputus total. Material longsor yang terdiri lumpur dan pasir menutup badan jalan sepanjang lebih dari 50 meter di Desa Ngadimulyo. Di lokasi juga terdapat satu rumah yang ambruk akibat diterjang longsor.
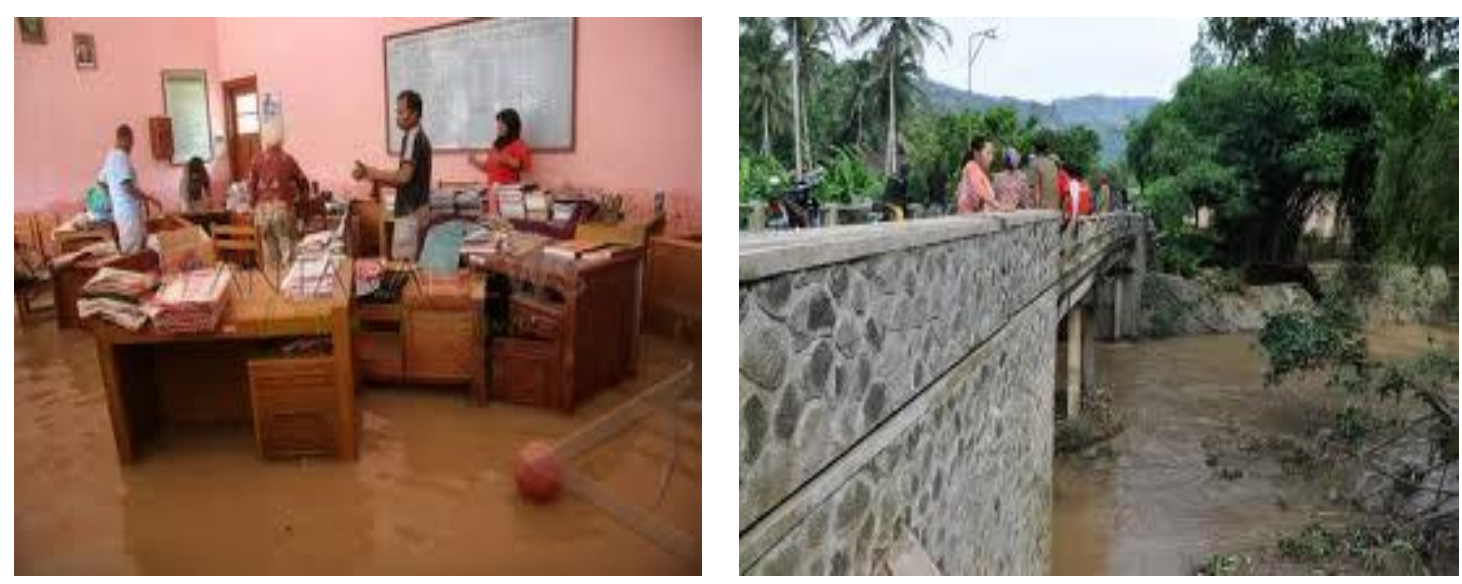

SMPN Kampak tergenang banjir $(50 \mathrm{~m})$ dari Sungai Tawing

Berdasarkan hasil pengamatan di lokasi penelitian, keberadaan TPA yang berada di bibir sungai juga memperburuk kualitas air dan kondisi sungai secara keseluruhan. Kondisi air pada saat musim kemarau menjadi keruh dengan sampah-sampah plastik bertebaran di sungai. Tempat pembuangan sampah 3-5m dari bibir Sungai Tawing

\section{Deskripsi Masyarakat Di Kawasan Sungai Tawing}

Kecamatan Kampak kabupaten Trenggalek, dari sudut geografis dikelilingi oleh pegunungan dengan jumlah penduduk 37.814 dengan jumlah kepala Keluarga ( KK ) 10.322 dengan Jumlah KK yang tergolong kurang mampu dalam peta sosial sebanyak 4.039 (Data berdasarkan Sensus Penduduk tahun 2010). Mata Pencaharian Masyarakat Di Kawasan sungai tawing Sebagian besar (28\%) masyarakat di kawasan sungai Tawing bermata pencaharian sebagai petani, pedagang dan bekerja di bidang jasa seperti, ojek, tukang becak dan kuli angkut di pasar. Adapun tingkat pendapatan rata-rata antara Rp.500.000 - Rp. 2000.000,00 (52\%). Penghasilan terendah di bawah Rp.500.000 mencapai (38.67\%) selebihnya $(9,2 \%)$ berpenghasilan di atas Rp.2000.000,00. 


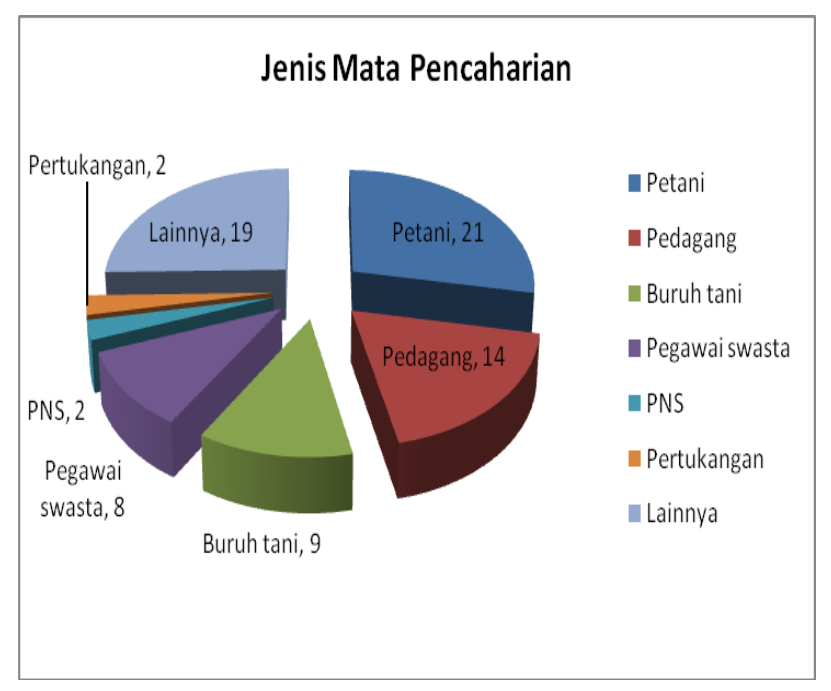

\section{Peran Pemangku Kepentingan Dalam Revitalisasi Sungai Tawing}

Berpijak dari bencana banjir yang terjadi, dan mengamati manajemen penanganan serta kesiapsiagaan masyarakat dalam menghadapi bencana yang terjadi di Trenggalek, peneliti memandang penting peran para pemangku kepentingan, baik dari pihak pemerintah, lembaga swadaya masyarakat atau tokoh-tokoh lokal yang memiliki pengaruh untuk melakukan langkah-langkah dalam revitalisasi sungai Tawing.

Selain itu, dalam upaya melakukan pengelolaan lingkungan dan mengurangi resiko bencana banjir, langkah revitalisasi sungai banyak ditempuh oleh pemerintah di berbagai daerah di Indonesia. Salah satu contoh daerah yang melakukan langkah ini adalah pemerintah Kota Bandung dan Pemprof DKI Jakartadalam melakukan revitalisasi sungai Cikapundung. Pemerintah Kota Bandung telah memasukkan Sungai Cikapundung dalam salah satu prioritas program kegiatan dalam rencana pembangunan, baik jangka menengah (2009-2013) dan jangka panjang (2005-2025). Rehabilitasi Sungai Cikapundung pun dicanangkan misalnya melalui program Gerakan Cikapundung Bersih yang didukung oleh Pemerintah Propinsi Jawa Barat dan Pemerintah Pusat. Revitalisasi sungai Cikapundung yang ditempuh pemerintah kota Bandung adalah melibatkan melibatkan lima kelurahan di tiga kecamatan, yaitu Kelurahan Lebak Siliwangi dan Cipaganti, (Kecamatan Coblong), Kelurahan Tamansari, (Kecamatan Bandung Wetan), serta Kelurahan Babakan Ciamis dan Braga, (Kecamatan Sumur Bandung). Model revitalisasi seperti ini layak dijadikan 
model untuk dikembangkan dalam upaya revitalisasi sungai Tawing di Kabupaten Trenggalek.

Mengapa model revitalisasi ini perlu dikembangkan? Permasalahan terkait sungai yang dihadapi berbagai daerah di Indonesia memiliki pola yang hampir sama yaitu antara lain pengelolaan sampah, pengelolaan mata air, serta septic tank sebagaimana terlihat pada gambar 1 terkait dengan fungsi sungai yang tidak hanya berfungsi untuk sistem irigasi, namun juga digunakan oleh warga sekitar untuk membuang limbah rumah tangga. Karena itu revitalisasi sungai tawing perlu melihat juga bagaimana penataan kawasan yang juga akan meliputi pembuatan atau revitalisasi saluran air bersih, drainase, septic tank dan pengelolaan sampah. Jika revitalisasi berjalan dengan baik, penting melibatkan swasta untuk mengembangkan kawasan sungai menjadi kawasan wisata seperti Wisata Pancing, Wisata Arung Jeram Wisata Susur Sungai dan sebagainya.

Selain dari pihak pemerintah kabupaten dan kecamatan setempat (kecamatan Kampak) dalam upaya revitalisasi perlu mengakomodir dan dengan melibatkan pemangku kepentingan dari komponen kelompok-kelompok pemuda pencinta alam dan lingkungan yang berada di wilayah kabupaten Trenggalek. Berdasarkan hasil penelitian terdahulu (Windiani, dkk: 2011) adanya komunitas pemuda pecinta lingkungan "DPR (Di Bawah Pohon Rindang) Community perlu dioptimalkan dan dilibatkan dalam revitalisasi sungai Tawing. Sejak tahun 2006 komunitas pemuda peduli lingkungan sudah berkontribusi nyata dalam melakukan pelestarian lingkungan seperti, reboisasi, susur sampah di kawasan pantai, pengelolaan sampah organik dan berecana membangkan model pengelolaan bank sampah seperti yang telah berkembang di berbagai daerah di Indonesia. Tidak ada orang yang suka berarung jeram di sungai kotor yang penuh sampah. Pengunjung pun tentu enggan untuk mengunjungi tempat wisata yang kotor dan tidak terjaga. Karenanya, untuk berkembang, perlu upaya bersama untuk sama-sama menjaga kebersihan lingkungan. Jika kegiatan dan kawasan ini nantinya dapat berkembang, akan ada potensi pengembangan ekonomi bagi warga sekitar, khususnya yang berada di sepanjang jalur yang akan dilewati, misalnya dengan membuka warung, menjadi tenaga pendamping, membersihkan jalur, mendaur-ulang sampah untuk dijual. 


\section{Kesimpulan}

Revialisasi sungai Tawing menjadi kebutuhan mendesak untuk dilakukan di kabupaten Trenggalek. Bencana banjir yang sering terjadi di wilayah kecamatan Kampak dan sekitarnya membutuhkan penanganan yang serius dari semua pihak khususnya para pemangku kepentingan baik pemerintah setempat, tokoh masyarakat, Komunitas pemuda maupun masyarakat yang ada di sekitar kawasan sungai. Terjadinya pendangkalan sungai Tawing tidak hanya terjadi secara alamiah, namun juga diperparah oleh aktifitas penduduk yang tinggal di sekitar kawasan sungai seperti; membuang sampah rumah tangga secara terus menerus, membuang limbah ternak, maupun untuk MCK. Revitalisasi sungai dengan optimalisasi peran pemangku kepentingan yang sudah berhasil di berbagai daerah seperti Bandung dan Yogyakarta dapat dijadikan model untuk dikembangkan.

Jika revitalisasi dilakukan, Sungai Tawing yang selama ini berfungsi untuk irigasi pertanian, bisa lebih memberikan nilai tambah untuk kehidupan masyarakat baik secara ekonomi, sosial dan lingkungan menjadi lebih berkualitas. Revitalisasi sungai juga mampu memberikan dukungan lingkungan yang semakin sehat dan bersih sekaligus mendatangkan keuntungan (ekonomi) bagi warga setempat. Dengan demikian akan muncul kesadaran pula bahwa sungai bukanglah tong sampah atau pelimbahan yang panjang yang bisa diperlakukan semena-mena. 


\section{DAFTAR PUSTAKA}

Asdak, Chay, 2002, Fenomena Banjir dan Kekurangan Air, Jurnal Ekologi dan Pembangunan, PPSDAL Lemlit Universitas Padjajaran, Bandung.

Darsoprajitno, H.Soewarno, 2002, Genangan dan Kekeringan, Jurnal Ekologi dan Pembangunan, PPSDAL Lemlit Universitas Padjajaran, Bandung.

Maryono, Agus, 2005, Menangani Banjir, Kekeringan dan Lingkungan, Gadjah Mada University Press, Yogyakarta.

Miles, Matthew B., Michael B. Huberman, 1984, Qualitative Data Analysis : A Source of New Methods, Sage Publications, London.

Puji Pujiono, 2005, Konsep Dasar Penanganan Bencana, Modul Pelatihan dalam Disaster Manajemen Training of Trainers 18 Nopember 2005, Probolinggo.

Soedarso, Windiani, 2007, Strategi Adaptasi Masyarakat Jember Terhadap Lingkungan Sekitarnya Pascabencana Banjir 2006, Laporan Penelitian Dosen Muda ITS, Surabaya. Sutikno, Prof. Dr., 2008, Rawan Bencana Minim Pengetahuan Industrialisasi Memperparah, Majalah Al-Falah bulan Februari, Surabaya.

Wahyono, Ary, dkk., 2001, Pemberdayaan Masyarakat, Media Pressindo, Yogyakarta. Windiani, dkk, 2011. Strategi Pengelolaan Limbah Domestik Di Kawasan Sungai Tawing, laporan Penelitian Dana Lokal ITS. 